\title{
ANALISIS FAKTOR YANG MEMPENGARUHI LABA BERSIH PERUSAHAAN ASURANSI PT JASA RAHARJA (PERSERO)
}

\author{
Dinar Riftiasari ${ }^{1}$, Sugiarti ${ }^{2}$ \\ ${ }^{1}$ Universitas Bina Sarana Informatika, dinar.drf@bsi.ac.id \\ ${ }^{2}$ Universitas Bina Sarana Informatika, sugiarti.ugt@bsi.ac.id
}

\begin{abstract}
ABSTRAK
PT Jasa Raharja (Persero) adalah BUMN yang mengelola asuransi kecelakaan lalu lintas dengan menghimpun dana bersumber dari pendapatan premi, investasi kemudian menyalurkan dengan klaim. Tujuan penelitian menganalisis pendapatan premi, hasil investasi, beban klaim terhadap laba bersih menggunakan korelasi secara parsial, determinasi dan regresi linier berganda. Penelitian menggunakan metode kuantitatif. Teknik analisa regresi linier berganda menggunakan software IBM SPSS 21. Sampel yang digunakan adalah data sekunder keuangan PT Jasa Raharja (persero) 2009-2017. Hasil penelitian uji koefisien korelasi secara parsial diperoleh pendapatan premi dan hasil investasi memiliki hubungan signifikan terhadap laba bersih sebesar 0,916 dan 0,844 hubungan sangat kuat dan searah, beban klaim terhadap laba bersih tidak terdapat hubungan secara parsial, secara simultan pendapatan premi, hasil investasi, dan beban klaim hubungan sangat kuat dan searah sebesar 0,994. Hasil uji koefisien determinasi menunjukkan pengaruh yang signifikan sebesar $98,8 \%$.
\end{abstract}

Kata Kunci: Pendapatan Premi, Hasil Investasi, Beban Klaim, Laba Bersih

\section{ABSTRACT}

PT Jasa Raharja (Persero) is a state-owned company that manages traffic accident insurance by collecting funds sourced from premium incomes, investment and then channeling it with claims. The purpose this research is to analyze premium income, investment result, claims expense on net profit using partial correlation, determination and multiple linear regression. This Research was quantitative methods. Multiple linear regression analysis techniques IBM SPSS 21. The sample used is secondary data the financial PT Jasa Raharja 2009-2017. The results of partial correlation coefficient test results obtained premium income and investment result significant relationship to net profit 0.916 and 0.844 very strong and direct relationship, claim expense on net profit is not partially related, simultaneously premium income, investment result, claim expenses very strong and unidirectional relationship 0.994. The coefficient of determination test results showed a significant effect $98.8 \%$.

Keywords: Premium Incomes, Investment Result, Claim Expense, Net Profit

Naskah diterima: 11-03-2020, Naskah dipublikasikan: 30-04-2020

\section{PENDAHULUAN}

Asuransi adalah perjanjian dua pihak antara perusahaan asuransi dan pemegang polis menjadikan dasar premi yang diterima sebagai imbalan bagi perusahaan asuransi berdasarkan Undang-undang Republik Indonesia No 40 Tahun 2014 dalam (Agustiranda, Yuliani, \& Samadi, 2019). Memiliki asuransi merupakan hal yang wajib dimiliki bagi masyarakat Indonesia dimana memberikan manfaat sebagai perlindungan diri, salah satunya adalah jenis asuransi kecelakaan lalu lintas sebagai perlindungan risiko kecelakaan pada saat berkendara. Di Indonesia perusahaan asuransi kecelakan milik negara adalah PT Jasa Raharja yang memberikan perlindungan kecelakaan bagi penumpang kendaraan umum dan kecelakaan korban lalu lintas. Dengan menelusuri laba bersih perusahaan asuransi PT Jasa Raharja setiap 
tahunnya atau membandingkan perubahan besarnya pendapatan dan beban terhadap laba bersih maka dapat diketahui keberhasilan operasional perusahaan dalam periode tertentu.

Pada perusahaan asuransi pendapatan premi memiliki peranan penting dalam membiayai kelangsungan kegiatan perusahaan. Menurut (Sastri, Edy, \& NI Kadek, 2017) perolehan pendapatan Premi bukan hanya sebagai profit bagi perusahaan melainkan juga merupakan kewajiban untuk masa yang akan datang. Premi yang diperoleh dijadikan sebagai cadangan premi untuk pembayaran apabila terjadi klaim.

Sumber pendapatan perusahaan salah satunya adalah perusahaan melakukan kegiatan investasi sebagai sumber modal perusahaan dimasa depan (Marwansyah \& Utami, 2017). Pengelolaan investasi yang baik dapat mengakomodasi tingkat resiko investasi yang dapat ditoleransi oleh perusahaan dengan hasil investasi yang sesuai, sehingga hasilnya dapat meningkatkan kinerja laba-rugi perusahaan menurut (Sastri, Edy, \& NI Kadek, 2017).

Dalam laporan keuangan bagian terpenting adalah laporan laba rugi sebagai unsur utama terdiri atas pendapatan dan beban. Pada perusahaan asuransi jiwa, pendapatan diperoleh dari pembayaran premi oleh nasabah dan beban klaim yaitu kewajiban perusahaan kepada nasabah/pemegang polis dalam (Tangkere, Ventje, \& Heince, 2017).

Penelitian terdahulu yang dilakukan oleh Marwansyah \& Utami (2017) membuktikan bahwa Analisis hasil Investasi, Pendapatan Premi, dan Beban Klaim, Terhadap Laba Perusahaan Perasuransian di Indonesia secara korelasi parsial memiliki hubungan signifikan.

Penelitian Agustiranda, Yuliani, dan Samadi (2019) meunjukkan bahwa pendapatan premi berpengaruh positif signifikan terhadap pertumbuhan laba perusahaan, pembayaran klaim tidak berpengaruh signifikan terhadap pertumbuhan laba dan risk based capital berpengaruh positif signifikan terhadap pertumbuhan laba.

Berdasarkan uraian latar belakang diatas maka rumusan masalah dalam penelitian ini adalah:

1. Apakah terdapat hubungan yang signifikan secara parsial dan simultan antara Pendapatan premi, hasil investasi dan klaim terhadap Laba bersih PT Jasa Raharja (persero)?

2. Apakah terdapat pengaruh yang signifikan secara simultan antara Pendapatan premi, hasil investasi dan klaim terhadap Laba bersih PT Jasa Raharja (persero)?

3. Apakah persamaan regresi berganda yang terbentuk antara Pendapatan premi, hasil investasi dan klaim terhadap Laba bersih PT Jasa Raharja (persero) signifikan?

\section{KAJIAN LITERATUR \\ Asuransi}

Pengertian asuransi merupakan perjanjian dinyatakan dalam kitab Undang-undang Hukum Dagang (KUHD) pasal 246, bahwa Asuransi atau pertanggungan adalah suatu perjanjian dengan mana seorang penanggung mengikatkan diri kepada seorang tertanggung, dengan menerima suatu premi, untuk penggantian kepadanya karena suatu kerugian, kerusakan atau kehilangan keuntungan yang diharapkan yang mungkin akan dideritanya karena suatu peristiwa yang tidak tentu.

Pengertian asuransi menurut pasal 1 angka 1 Undang-undang No 2 Tahun 1992 menyatakan bahwa asuransi atau pertanggungan adalah perjanjian antara 2 pihak atau lebih dengan mana pihak penanggung mengikatkan diri kepada tertanggung dengan menerima premi asuransi untuk memberikan penggantian kepada tertanggung karena kerugian, kerusakan, atau kehilangan keuntungan yang diharapakan, atau tanggung jawab hukum kepada pihak ketiga yang mungkin akan diderita tertanggung yang timbul dari suatu peristiwa yang tidak pasti, atau untuk memberikan suatu pembayaran yang didasarkan atas meninggal atau hidupnya seseorang yang dipertanggungkan dalam (Rastuti, 2016). 


\section{Laba Bersih}

Menurut (Fraser M \& Aileen, 2018) laba bersih (net earning "bottom line") menunjukkan laba perusahaan setelah pertimbangan seluruh pendapatan dan beban yang dilaporkan selama periode akuntansi tertentu. Marjin laba bersih (net profit margin) memperlihatkan presentase laba yang dihasilkan oleh setiap dolar penjualan. Sedangkan menurut (Kasmir, 2012) Laba bersih (net profit), laba yang telah dikurangi biaya-biaya yang merupakan beban perusahaan dalam suatu periode tertentu, termasuk pajak. Peningkatan laba perusahaan pada akhirnya akan meningkatkan nilai perusahaan, karena semakin tinggi pertumbuhan laba perusahaan berarti semakin besar dividen yang akan dibayar perusahaan kepada para pemegang saham menurut Simomangkir dalam (Agustiranda, Yuliani, \& Samadi, 2019).

\section{Pendapatan Premi}

Menurut Standar Akuntansi Keuangan PSAK No 36 tentang Akuntansi Kontrak Asuransi Jiwa dalam (Tangkere, Ventje, \& Heince, 2017) pendapatan premi terdiri dari:

a) Premi Kontrak Asuransi Jangka Pendek (Paragraf 05)

Premi kontrak asuransi jangka pendek diakui sebagai pendapatan dalam periode kontrak sesuai dengan proporsi jumlah proteksi asuransi yang diberikan. Jika periode risiko berbeda secara signifikan dengan peroide kontrak, maka premi diakui sebagai pendapatan selama periode resiko sesuai dengan proporsi jumlah proteksi asuransi yang diberikan.

b) Premi Selain Kontrak Asuransi Jangka Pendek (Paragraf 06)

Premi selain kontrak asuransi jangka pendek diakui sebagai pendapatan pada saat jatuh tempo dari pemegang polis. Kewajiban untuk biaya yang diharapkan timbul sehubungan dengan kontrak tersebut diakui selama periode sekarang dan periode diperbaruinya kontrak.

Pendapatan premi merupakan sejumlah uang yang dibayarkan pihak tertanggung atas imbalan jasa dari perlindungan yang diberikan pihak penanggung sesuai dengan perjanjian yang disepakati sebelumnya menurut (Sastri, Edy, \& NI Kadek, 2017).

Premi adalah sejumlah uang yang dibayarkan oleh pihak tertenggung dan diterima oleh penanggung sebagai pengganti suatu kerusakan, kerugian maupun apabila terjadi kehilangan tertanggung kepada penanggung. Jumlah seberapa besar premi dapat ditentukan dari seleksi risiko yang dihasilkan oleh underwriter maupun apabila perusahaan telah menyeleksi risiko atas permintaan calon tertanggung sehingga calon tertanggung membayar premi asuransi sesuai tingkat risiko berdasarkan kondisinya masing-masing. Besarnya premi atas keikutsertaan di asuransi yang harus dibayarkan telah ditetapkan oleh perusahaan asuransi dengan memperhatikan keadaan-keadaan dari tertanggung. (Agustiranda, Yuliani, \& Samadi, 2019)

\section{Hasil Investasi}

Menurut (Halim, 2015) mengemukakan bahwa Investasi pada hakekatnya merupakan penempatan sejumlah dana pada saat ini dengan harapan untuk memperoleh keuntungan di masa mendatang.

Investasi erat kaitannya dengan dengan akumulasi suatu bentuk aktiva atau modal dengan suatu harapan mendapatkan keuntungan dimasa depan. Investasi juga sering disebut sebagai penanaman modal. Dalam (Abi, 2016) banyak ahli dan profesional memberikan pengertian investasi, antara lain:

1. Menurut Mulyadi investasi adalah pengaitan sumber-sumber dalam jangka panjang untuk mendapatkan laba di masa datang.

2. Menurut Henry Simamora investasi adalah suatu aktiva yang digunakan oelh perusahaan untuk menambahkan atau menumbuhkan kekayaan melalui distribusi hasil investasi untuk apresiasi nilai investasi atau juga untuk manfaat lain bagi suatu perusahaan yang berinvestasi, seperta manfaat yang diperoleh melalui hubungan dagang.

3. Menurut James $\mathrm{C}$ Van Horn investasi adalah kegiatan yang memanfaatkan kas pada saat sekarang dengan tujuan untuk mendapatkan hasil barang dimasa yang akan datang. 
4. Menurut Fitz Gerald investasi adalah aktivitas yang berkaitan dengan usaha penarikan sumbersumber yang dipakai untuk mengadakan modal barang pada saat sekarang. Barang modal tersebut kemudian akan menghasilkan aliran produk baru di masa yang akan datang.

5. Menurut Sunariyah investasi adalah penanaman modal untuk satu atau lebih aktiva yang dimiliki dan juga biasanya berjangka waktu lama dengan harapan untuk mendapatkan keuntungan di masa yang akan datang.

6. Menurut Kamus Besar Bahasa Indonesia investasi adalah penanaman uang atau modal dalam suatu perusahaan atau proyek untuk tujuan memperoleh keuntungan.

Jadi investasi adalah suatu aktivitas yang bertujuan untuk mendapatkan keuntungan di masa mendatang dengan memanfaatkan modal atau asset di masa sekarang.

\section{Beban Klaim}

Beban adalah arus keluar aktiva atau penggunaan lainnya atas aktiva atau terjadinya (munculnya) kewajiban entitas (atau kombinasi dari keduanya) yang disebabkan oleh pengiriman atau pembuatan barang, pemberian jasa, atau aktivitas lainnya yang merupakan operasi utama atau operasi sentral perusahaan (Hery, 2012)

Berdasarkan (Standar Akuntansi Keuangan, 2008) PSAK No 28 tentang Akuntansi Asuransi Kerugian, Klaim Bruto adalah klaim yang jumlahnya telah disepakati, termasuk biaya penyelesaian klaim.

Menurut Budi dalam (Agustiranda, Yuliani, \& Samadi, 2019) menyatakan klaim asuransi merupakan suatu tuntutan yang dilakukan oleh pihak tertanggung kepada pihak penanggung atas adanya kontrak perjanjian asuransi yang mengikat antar pihak dalam menjamin pembayaran ganti rugi apabila terjadi musibah yang dialami oleh pihak tertanggung, dimana dapat diklaim apabila premi telah dibayarkan oleh pihak tertanggung.

\section{Kerangka Konseptual}

Bagan kerangka_pemikiran penelitian seb_agai berikut:

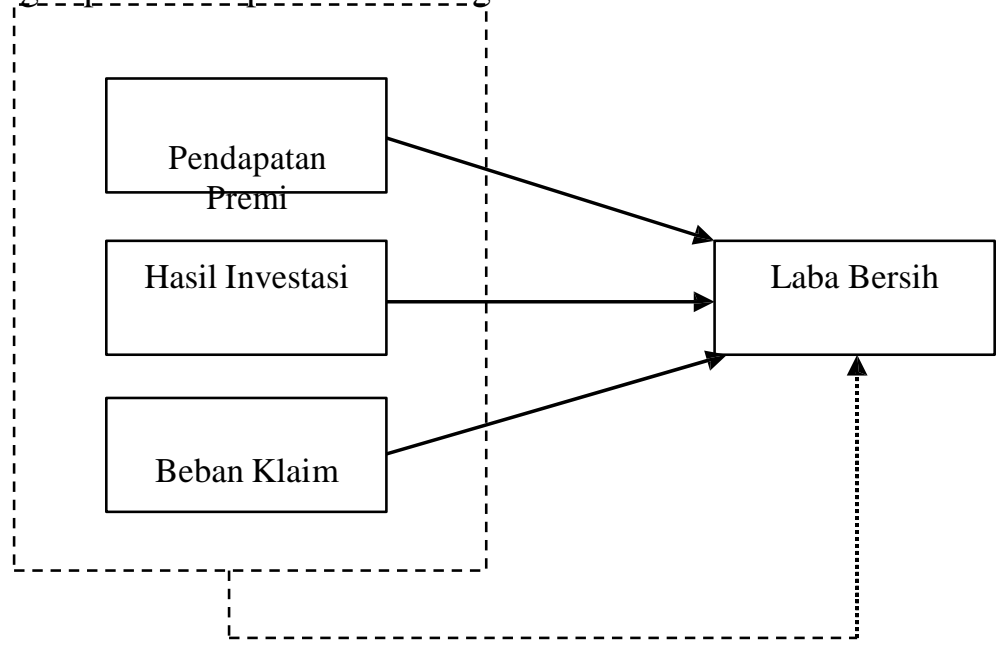

\section{Gambar 1 Kerangka Konseptual}

\section{Hipotesis Penelitian}

Berdasarkan kerangka pemikiran teoritis yang telah diuraikan diatas, maka hipotesis dalam penelitian ini yaitu:

$\mathrm{H}_{1}$ : Terdapat hubungan yang signifikan secara parsial antara pendapatan premi terhadap laba bersih.

$\mathrm{H}_{2}$ : Terdapat hubungan yang signifikan secara parsial antara hasil investasi terhadap laba bersih. 
$\mathrm{H}_{3}$ : Terdapat hubungan yang signifikan secara parsial antara beban klaim terhadap laba bersih.

$\mathrm{H}_{4}$ : Terdapat hubungan yang signifikan secara simultan antara pendapatan premi, hasil investasi, dan beban klaim terhadap laba bersih.

\section{METODE PENELITIAN}

Penelitian ini menggunakan pendekatan metode kuantitatif dimana data yang digunakan dalam penelitian ini adalah berbentuk angka. Teknik pengumpulan Data dalam penelitian menggunakan data sekunder yang bersumber dari laporan keuangan PT Jasa Raharja (Persero) dan Sampel penelitian adalah perusahaan PT Jasa Raharja periode 20092017. Teknik analisis data yang digunakan dalam penelitian adalah pengujian koefisien korelasi, uji koefisien determinasi, dan regresi linier berganda.

\section{Koefisien Korelasi}

Menurut (Sujarweni, 2016) korelasi merupakan salah satu statistik yang akan menguji apakah dua variabel atau lebih yang ada mempunyai hubungan atau tidak. rumus Uji Koefisien Korelasi yaitu sebagai berikut:

$$
r=\frac{n \Sigma X Y-\Sigma X \Sigma Y}{\sqrt{\left[n \Sigma X^{2}-(\Sigma \mathrm{X})^{2}\left[\mathrm{n} \Sigma \mathrm{Y}^{2}-(\Sigma \mathrm{Y})^{2}\right]\right.}}
$$

$$
\begin{aligned}
& \text { Keterangan: } \\
& \begin{aligned}
\mathrm{n} \quad & =\text { banyaknya pasangan data } \mathrm{X} \text { dan } \mathrm{Y} \\
\sum \mathrm{X} & =\text { total jumlah dari variabel } \mathrm{X} \\
\sum \mathrm{Y} & =\text { total jumlah dari variabel } \mathrm{Y} \\
\sum \mathrm{X}^{2} & =\text { kuadrat dari total jumlah variabel } \mathrm{X} \\
\sum \mathrm{Y}^{2} & =\text { kuadrat dari total jumlah variabel } \mathrm{Y} \\
\sum \mathrm{XY} & =\text { hasil perkalian dari total jumlah variabel } \mathrm{X} \text { dan variabel }
\end{aligned}
\end{aligned}
$$

Koefisien korelasi memiliki nilai antara -1 hingga +1 . Sifat nilai koefisien korelasi yaitu antara plus (+) atau minus (-). Korelasi positif artinya bahwa jika variabel $X^{1}$ mengalami kenaikan maka variabel $\mathrm{X}^{2}$ juga akan mengalami kenaikan, begitu pula sebaliknya. Sedangkan korelasi negatif berarti bahwa jika variabel $X^{1}$ mengalami penurunan maka variabel $X^{2}$ akan mengalami kenaikan, dan sebaliknya.

\section{Tabel 1}

Tingkat Hubungan Koefisien Korelasi

\begin{tabular}{|c|c|}
\hline Internal Koefisien & Tingkat Hubungan \\
\hline $0,00-0,020$ & Sangat Lemah \\
\hline $0,21-0,40$ & Lemah \\
\hline $0,41-0,70$ & Kuat \\
\hline $0,71-0,90$ & Sangat Kuat \\
\hline $0,91-0,99$ & Kuat Sekali \\
\hline 1 & Sempurna \\
\hline
\end{tabular}

Sumber: (Sujarweni, 2016) 


\section{Koefisien Determinasi}

Menurut (Supardi, 2013) Koefisien determinasi dilambangkan dengan $r^{2}$. Nilai ini menyatakan proporsi variasi keseluruhan dalam nilai variabel dependent yang dapat diterangkan atau diakibatkan oleh hubungan linear dengan variabel independent, selain itu (sisanya) diterangkan oleh variabel yang lain (galat atau peubah nilainya). Nilai koefisien determinasi dinyatakan dalam kuadrat dari nilai koefisien korelasi $r^{2} \times 100 \%=\mathrm{n} \%$, memiliki makna bahwa nilai variabel dependent dapat diterangkan oleh variabel independent sebesar $\mathrm{n} \%$, sedangkan sisanya sebesar (100-n)\% diterangkan oleh galat (error) atau pengaruh variabel yang lain.

Koefisien Determinasi dirumuskan:

$\mathrm{KD}=r^{2} \times 100 \%$

$\mathrm{KD}=$ Koefisien Determinasi

$r \quad=$ Koefisien Korelasi

\section{Koefisien Regresi Linear Berganda}

Penerapan metode regresi berganda jumlah variabel bebas (independent) yang digunakan lebih dari satu yang mempengaruhi satu variabel tak bebas (dependent). menurut Syofian Siregar dalam (Riftiasari \& Sugiarti, 2019) Rumus regresi linear berganda:

$\mathrm{Y}=\mathrm{a}+\mathrm{b} 1 \mathrm{X} 1+\mathrm{b} 2 \mathrm{X} 2+\mathrm{b} 3 \mathrm{X} 3 \ldots+\mathrm{bnXn}$

Dimana:

$\mathrm{Y}=$ Variabel terikat, $\mathrm{X} 1=$ Variabel bebas pertama, $\mathrm{X} 2=$ Variabel bebas kedua

$\mathrm{X} 3=$ Variabel bebas ketiga, $\mathrm{Xn}=$ Variabel bebas ke.... $\mathrm{n}$ a dan $\mathrm{b} 1$ serta $\mathrm{b} 2=$ Konstanta

\section{HASIL DAN PEMBAHASAN}

Data Penelitian

Data Keuangan PT Jasa Raharja (Persero) periode 2009-2017 yang telah ditransformasikan ke dalam logaritma natural (LN) sebagai berikut:

Tabel 2

Data Penelitian Dalam Logaritma Natural (LN)

\begin{tabular}{|c|c|c|c|c|}
\hline Tahun & $\begin{array}{c}\text { Pendapatan } \\
\text { Premi (X1) }\end{array}$ & $\begin{array}{c}\text { Hasil } \\
\text { Investasi } \\
\text { (X2) }\end{array}$ & $\begin{array}{c}\text { Klaim } \\
(\times 3)\end{array}$ & $\begin{array}{c}\text { Laba } \\
\text { Bersih } \\
\text { (X) }\end{array}$ \\
\hline 2009 & 28,92394045 & 26,9970735 & 28,16337 & 27,89363 \\
\hline 2010 & 28,81962013 & 26,7564179 & 28,15925 & 27,75189 \\
\hline 2011 & 28,92394045 & 27,0025607 & 28,16337 & 27,98468 \\
\hline 2012 & 29,01200134 & 27,1213569 & 28,13679 & 28,16151 \\
\hline 2013 & 29,08479579 & 27,0669379 & 28,06918 & 28,28316 \\
\hline 2014 & 29,14066572 & 27,3839406 & 28,07923 & 28,49388 \\
\hline 2015 & 29,21211133 & 27,1805533 & 28,1734 & 28,47362 \\
\hline 2016 & 29,24697997 & 27,4799461 & 28,27746 & 28,49684 \\
\hline 2017 & 29,33367538 & 27,591776 & 28,52041 & 28,38394 \\
\hline
\end{tabular}

Sumber: Data diolah menggunakan IBM SPSS 21

\section{Uji Koefisien Korelasi}

Berikut merupakan hasil output IBM SPSS 21 dan pengambilan keputusan serta kesimpulan mengenai hubungan secara parsial dan simultan antara variabel bebas $\left(\mathrm{X}_{1}, \mathrm{X}_{2}\right.$ dan $\left.\mathrm{X}_{3}\right)$ terhadap variabel terikat $(\mathrm{Y})$ : 
1. Uji koefisien korelasi secara parsial antara pendapatan premi $\left(\mathrm{X}_{1}\right)$ terhadap laba bersih $(\mathrm{Y})$, apabila hasil investasi $\left(\mathrm{X}_{2}\right)$ dan beban klaim $\left(\mathrm{X}_{3}\right)$ sebagai pengendali (dibuat konstan).

\section{Tabel 3}

\section{Correlations}

\begin{tabular}{|c|c|c|c|c|c|}
\hline & & $\begin{array}{l}\text { Pendapatan } \\
\text { Premi } \\
\end{array}$ & inxestasi & $\begin{array}{l}\text { Beban } \\
\text { Klaim } \\
\end{array}$ & $\begin{array}{l}\text { Laba } \\
\text { Bersih }\end{array}$ \\
\hline \multirow{4}{*}{$\begin{array}{l}\text { Pendapatan } \\
\text { Premi }\end{array}$} & Pearson Correlation & 1 & $.928^{*}$ & .579 & $.916^{\circ}$ \\
\hline & Sig. (2-tailed) & & .000 & -102 & .001 \\
\hline & $\mathrm{N}$ & 9 & 9 & 9 & 9 \\
\hline & Pearson Correlation & $-928^{\circ}$ & 1 & .619 & $.844^{-}$ \\
\hline \multirow[t]{3}{*}{ Inyestasi } & Sig. (2-tailed) & .000 & & .075 & .004 \\
\hline & $\mathrm{N}$ & 9 & 9 & 9 & 9 \\
\hline & Pearson Correlation & .579 & .619 & 1 & .224 \\
\hline \multirow[t]{3}{*}{ Beban Klaim } & Sig. (2-tailed) & -102 & .075 & & .561 \\
\hline & $N$ & 9 & 9 & 9 & 9 \\
\hline & Pearson Correlation & $-916^{-}$ & $844^{*}$ & .224 & 1 \\
\hline \multirow[t]{2}{*}{ Laba Bersih } & Sig. (2-tailed) & .001 & .004 & -561 & \\
\hline & $\mathrm{N}$ & 9 & 9 & 9 & 9 \\
\hline
\end{tabular}

Sumber: Data diolah menggunakan IBM SPSS 21

Hipotesis :

$\mathrm{Ho}_{1}$ : Tidak terdapat hubungan yang signifikan secara parsial antara pendapatan premi terhadap laba bersih.

$\mathrm{Ha}_{1}$ : Terdapat hubungan yang signifikan secara parsial antara pendapatan premi terhadap laba bersih.

Pengambilan keputusan :

Jika Sig <, maka Ho ditolak.

Jika Sig > , maka Ho diterima.

Berdasarkan tabel 3 correlation diatas didapat nilai signifikan untuk variabel pendapatan premi $\left(\mathrm{X}_{1}\right)$ sebesar $0.001<0.05$ sehingga Ho ditolak yang artinya terdapat hubungan secara parsial antara pendapatan premi terhadap laba bersih. Sedangkan untuk nilai pearson correlation sebesar 0.916 , yang artinya hubungan antara pendapatan premi dan laba bersih adalah sangat kuat dan searah.

2. Uji koefisien korelasi secara parsial antara hasil investasi $\left(\mathrm{X}_{2}\right)$ terhadap laba bersih $(\mathrm{Y})$, apabila pendapatan premi $\left(\mathrm{X}_{1}\right)$ dan beban klaim $\left(\mathrm{X}_{3}\right)$ sebagai pengendali (dibuat konstan).

Hipotesis :

$\mathrm{Ho}_{2}$ : Tidak terdapat hubungan yang signifikan secara parsial antara hasil investasi terhadap laba bersih.

$\mathrm{Ha}_{2}$ : Terdapat hubungan yang signifikan secara parsial antara hasil investasi terhadap laba bersih.

Berdasarkan tabel 3 correlations diatas didapat nilai signifikansi untuk variable hasil investasi $\left(\mathrm{X}_{2}\right)$ terhadap laba bersih sebesar $0.004<0.05$ sehingga Ho ditolak yang artinya terdapat hubungan secara parsial antara hasil investasi terhadap laba bersih. Sedangkan untuk nilai pearson correlation sebesar 0.844 , yang artinya hubungan antara pendapatan hasil investasi dan laba bersih adalah sangat kuat dan searah.

3. Uji koefisien korelasi secara parsial antara beban klaim $\left(\mathrm{X}_{3}\right)$ terhadap laba bersih $(\mathrm{Y})$, apabila pendapatan premi $\left(\mathrm{X}_{1}\right)$ dan hasil investasi $\left(\mathrm{X}_{2}\right)$ sebagai pengendali (dibuat konstan).

Hipotesis : 
$\mathrm{Ho}_{3}$ : Tidak terdapat hubungan yang signifikan secara parsial antara beban klaim terhadap laba bersih.

$\mathrm{Ha}_{3}$ : Terdapat hubungan yang signifikan secara parsial antara beban klaim terhadap laba bersih.

Berdasarkan tabel 3 correlation diatas didapat nilai signifikansi untuk variable $\operatorname{Klaim}\left(\mathrm{X}_{3}\right)$ terhadap laba bersih sebesar $0.561>0.05$ sehingga Ho diterima yang artinya tidak terdapat hubungan secara parsial antara klaim terhadap laba bersih.

4. Uji koefisien korelasi secara simultan antara pendapatan premi $\left(X_{1}\right)$, hasil investasi $\left(X_{2}\right)$ dan beban klaim $\left(\mathrm{X}_{3}\right)$ terhadap laba bersih $(\mathrm{Y})$

Hipotesis :

$\mathrm{Ho}_{4}$ : Tidak terdapat hubungan yang signifikan secara simultan antara pendapatan premi, hasil investasi, dan beban Klaim terhadap laba bersih.

$\mathrm{Ha}_{4}$ : Terdapat hubungan yang signifikan secara simultan antara pendapatan premi, hasil investasi, dan beban klaim terhadap laba bersih.

Tabel 4

Model Summary

\begin{tabular}{|c|c|c|c|c|c|c|c|c|c|}
\hline \multirow[t]{2}{*}{ Model } & \multirow[t]{2}{*}{$\mathrm{R}$} & \multirow{2}{*}{$\begin{array}{l}\mathrm{R} \\
\text { Square }\end{array}$} & \multirow{2}{*}{$\begin{array}{l}\text { Adjusted } \\
\text { R Square }\end{array}$} & \multirow{2}{*}{$\begin{array}{l}\text { Std. Error of } \\
\text { the Estimate }\end{array}$} & \multicolumn{5}{|c|}{ Change Statistics } \\
\hline & & & & & $\begin{array}{l}\mathrm{R} \text { Square } \\
\text { Change }\end{array}$ & $\begin{array}{l}\mathrm{F} \\
\text { Change } \\
\end{array}$ & df1 & df2 & Sig. F Change \\
\hline 1 & $\begin{array}{l}.994 \\
a\end{array}$ & .988 & .981 & .039252 & .988 & $\begin{array}{l}135.13 \\
4\end{array}$ & 3 & 5 & .000 \\
\hline
\end{tabular}

a. Predictors: (Constant), peban klaim, pendapatan premi, hasil inyestasi

Sumber: Data diolah menggunakan IBM SPSS 21

Berdasarkan tabel 4 Model Summary diatas, nilai Sig. $F_{\text {Change }}$ yang diperoleh sebesar $0.000<0.05$, maka Ho ditolak yang artinya terdapat hubungan secara simultan antara pendapatan premi, hasil investasi dan beban klaim terhadap Laba bersih. Nilai koefisien korelasi (R) secara simultan yang didapat sebesar 0.994 , artinya hubungan antara pendapatan premi, hasil investasi dan beban klaim secara simultan adalah sangat kuat dan searah.

\section{Uji Koefisien Determinasi}

Berikut merupakan hasil output IBM SPSS 21 dan pengambilan keputusan serta kesimpulan mengenai koefisien determinasi secara simultan antara variabel bebas $\left(\mathrm{X}_{1}, \mathrm{X}_{2} \& \mathrm{X}_{3}\right)$ terhadap variabel terikat adalah 0.988 atau $98,8 \%$. Artinya, laba bersih dipengaruhi oleh pendapatan premi, hasil investasi dan beban klaim sebesar $98,8 \%$ sisanya sebesar $1,2 \%$ dipengaruhi oleh faktor lain di luar model selain dari faktor yang diwakili variabel bebas (pendapatan premi, hasil investasi dan beban klaim) seperti pendapatan komisi reasuransi, pendapatan operasi lainnya, beban operasional dan komisi, beban manajemen dan usaha.

\section{Uji Regresi Linier Berganda}

Berikut merupakan hasil output IBM SPSS 21 dan pengambilan keputusan serta kesimpulan mengenai uji regresi linier berganda antara variabel bebas $\left(X_{1}, X_{2} \& X_{3}\right)$ terhadap variabel terikat $(\mathrm{Y})$ :

Tabel 5

Coefficientsa

\begin{tabular}{|c|c|c|c|c|c|c|}
\hline \multirow{2}{*}{\multicolumn{2}{|c|}{ Model }} & \multicolumn{2}{|c|}{ Unstandardized Coefficients } & \multirow{2}{*}{$\begin{array}{c}\text { Standardized } \\
\text { Coefficients } \\
\text { Beta } \\
\end{array}$} & \multirow[t]{2}{*}{$\mathrm{t}$} & \multirow[t]{2}{*}{ Sig. } \\
\hline & & $\mathrm{B}$ & Std. Error & & & \\
\hline \multirow{4}{*}{1} & (Constant) & 3.409 & 4.030 & & .846 & .436 \\
\hline & pendapatan premi & 1.603 & .221 & .978 & 7.242 & .001 \\
\hline & hasil inyestasi & .257 & .148 & .242 & 1.732 & .144 \\
\hline & klaim & -1.021 & 131 & -.496 & -7.781 & .001 \\
\hline
\end{tabular}

a. Dependent Variable: laba bersih

http://ejournal.stıemj.ac.1d/1ndex.php/akuntans1 
Sumber: Data diolah menggunakan IBM SPSS 21

Berdasarkan hasil output dari tabel 5 coefficients diatas, dapat diperoleh persamaan regresi linier berganda sebagai berikut:

$Y=a+b_{1} X_{1}+b_{2} X_{2}+b_{3} X_{3}$

$\mathrm{Y}=3.409+1.603 \mathrm{X}_{1}+0.257 \mathrm{X}_{2}-1.021 \mathrm{X}_{3}$ berikut:

Berdasarkan persamaan regresi berganda yang terbentuk dapat dianalisis sebagai

1. Nilai konstanta yang diperoleh sebesar 3.409 bernilai positif. Jika nilai pendapatan premi $\left(\mathrm{X}_{1}\right)$, hasil investasi $\left(\mathrm{X}_{2}\right)$, dan beban klaim $\left(\mathrm{X}_{3}\right)$ bernilai 0 maka diperkirakan nilai laba bersih sebesar 3.409

2. Nilai koefisien regresi $X_{1}$ sebesar 1.603 yang menyatakan bahwa setiap penambahan satu nilai, maka akan meningkatkan nilai Y sebesar 1.603

3. Nilai koefisien regresi $\mathrm{X}_{2}$ sebesar 0.257 yang menyatakan bahwa setiap penambahan satu nilai, maka akan meningkatkan nilai Y sebesar 0.257

4. Nilai koefisien regresi $\mathrm{X}_{3}$ sebesar -1.021 menyatakan bahwa setiap penambahan satu nilai, maka akan menurunkan nilai Y sebesar -1.021

\section{PENUTUP} berikut:

Berdasarkan penelitian yang telah dilakukan maka dapat diambil kesimpulan sebagai

Secara korelasi parsial terdapat hubungan yang signifikan antara pendapatan premi $\left(\mathrm{X}_{1}\right)$ terhadap laba bersih (Y) hubungan sangat kuat dan searah sebesar 0,916. Antara hasil investasi $\left(\mathrm{X}_{2}\right)$ terhadap laba bersih $(\mathrm{Y})$ secara korelasi parsial terdapat hubungan yang signifikan hubungan yang diperoleh sangat kuat dan searah sebesar 0,844. Sedangkan antara beban klaim $\left(\mathrm{X}_{3}\right)$ terhadap laba bersih $(\mathrm{Y})$ tidak terdapat hubungan secara parsial. Secara simultan (bersamasama) terdapat hubungan sangat kuat dan searah sebesar 0,994 antara pendapatan premi, hasil investasi, dan beban klaim terhadap laba bersih.

Secara simultan (bersama-sama) antara pendapatan premi, hasil investasi dan beban klaim mempengaruhi laba bersih sebesar 98,8\% sementara itu 1,2\% sisanya merupakan pengaruh dari faktor-faktor lain selain dari faktor yang diwakili variabel bebas (pendapatan premi, hasil investasi dan beban klaim).

Berdasarkan persamaan regresi berganda yang terbentuk dapat diartikan jika nilai variable $\mathrm{X}_{1}$ (pendapatan premi), $\mathrm{X}_{2}$ (hasil investasi) dan $\mathrm{X}_{3}$ (beban klaim) sama dengan nol maka nilai variable Y (laba bersih) 3.409 atau $3.4 \%$.

\section{Saran}

Bagi PT Jasa Raharja (persero) lebih meningkatkan pendapatan premi dan hasil investasi untuk mendapatkan hasil yang lebih maksimal dan perusahaan perlu menekan beban klaim sesuai anggaran yang disediakan sehingga mampu berkontribusi terhadap laba bersih perusahaan.

Bagi peneliti selanjutnya perlu penambahan variabel lain yang akan diuji dalam model penelitian dan periode yang jauh lebih banyak agar mendapatkan hasil yang valid dan optimal. 


\section{REFERENSI}

Abi, F. paulus P. (2016). Semakin Dekat Dengan Pasar Modal Indonesia (Peratama). Yogyakarta: Deepublish.

Agustiranda, W., Yuliani, \& Samadi, W. B. (2019). Pengaruh pendapatan premi, pembayaran

klaim, dan. Jurnal Ilmiah Manajemen Bisnis Dan Terapan, XIV(No 1 April), 1-12. Diambil dari https://ejournal.unsri.ac.id/index.php/jembatan/article/view/9220/pdf

Fraser M, L., \& Aileen, O. (2018). Memahami Laporan Keuangan (Kesembilan). Jakarta: Indeks.

Halim, A. (2015). Analisis Investasi Di Aset Keuangan. Jakarta: Mitra wacana Media.

Hery. (2012). Analisis Laporan Keuangan. Jakarta: PT Bumi Aksara.

Kasmir. (2012). Analisis Laporan keuangan. Jakarta: PT Raja Grafindo Persada.

Marwansyah, S., \& Utami, A. N. (2017). Analisis Hasil Investasi, Pendapatan Premi, Dan Beban Klaim Terhadap Laba Perusahaan Perasuransian Di Indonesia. Jurnal Akuntansi, Ekonomi dan Manajemen Bisnis, 5(No 2 Desember), 213-221. https://doi.org/10.30871/jaemb.v5i2.533

Rastuti, T. (2016). Aspek Hukum Perjanjian Asuransi. Yogyakarta: Medpress Digital.

Riftiasari, D., \& Sugiarti. (2019). The Analysis Of Warning Letter And Distress Warrant Against The Disbursement Of Tax Arrears At The North Jakarta Middle Tax Ofice. JASS (Journal of Accounting for Sustainable Society), 1(02), 158-167. https://doi.org/10.35310/jass.v1i02.234

Sastri, I. A. I. P., Edy, S., \& NI Kadek, S. (2017). Laba Perusahaan Asuransi. Akuntansi, 7(1). https://doi.org/10.1016/j.enfcli.2009.07.001

Standar Akuntansi Keuangan. (2008). Ikatan Akuntan Indonesia (Kedua). Jakarta: Salemba Empat.

Sujarweni, V. W. (2016). Kupas Tuntas Penelitian Akuntansi Dengan SPSS. Yogyakarta: Pustaka Baru press.

Supardi. (2013). Aplikasi Statistika Dalam Penelitian. Jakarta: Change Publication.

Tangkere, D. F. D., Ventje, I., \& Heince, W. (2017). Analisis Perlakuan Akuntansi Pendapatan Premi Dan Beban Klaim Pada Ajb Bumiputera 1912 Cabang Bitung. Jurnal Riset Ekonomi, Manajemen, Bisnis dan Akuntansi, 5(No 2 Juni), 1359-1368. Diambil dari https://ejournal.unsrat.ac.id/index.php/emba/article/view/16166 